\title{
History and Technological Significance of Hevea Rubber Production in Guatemala
}

\author{
Ray F. Dawson ${ }^{1}$ and F.W. Owen Smith ${ }^{2}$
}

\begin{abstract}
Additional index words. Hevea brasiliensis, South American leaf blight, Microcyclus ulei, Piedmont environment, disease resistance, environmental escape, latex production, industry organization, natural rubber markets
\end{abstract}

Summary. Production of rubber from Hevea brasiliensis (Willd. ex A. Juss) Muell.-Arg. (Euphorbiaceae) is greatest in southeastern Asia where the South American leaf blight disease is absent. Except for the Pacific Piedmont of Guatemala, plantation production in the Americas is limited severely by the now widespread presence of the pathogen Microcyclus ulei (P. Henn.) Arx. Mean latex yields from trees growing on the Piedmont approximate those of Indonesia and Malaysia, with little evidence of damage from leaf blight. The scope and scale of the Guatemalan anomaly suggest that environmentally modulated escape rather than previously assumed disease resistance may be the key to successful production of natural rubber in this hemisphere. The Guatemalan industry is presently well-organized to service regional markets in Mexico and the Caribbean Basin. Given due attention to environmental analysis, it may serve also as a model for the development of regional production facilities in other parts of tropical America.

$H$ evea brasiliensis (hereinafter designated simply Hevea) is the world's principal source of natural rubber. The tree was introduced to English-speaking horticulturists about 1823 (Wright and Dewar, 1900). When lacerated, the bark ex-

\footnotetext{
${ }^{1}$ Consultant in tropical agriculture (retired), 40 Palmer Avenue, Winter Park, FL 32789.

${ }^{2}$ Tropical agriculturist and member of the Gremial de Huleros de Guatemala.
}

udes a milky latex containing particulate cis- 1, 4-polyisoprene. Although native to the Amazon-Orinoco river basins of South America, the species has been selected and cultivated extensively in southeastern Asia to the point that it now yields about lo-fold the wild mean of latex, dry basis. The history and technologies of natural rubber production have been summarized recently by Webster and Baulkwill (1989).

Coincident with the growth of the automotive tire industry, and stimulated by the earlier (1870 to 1914) successes of the English in Malaysia and the Dutch in Indonesia, the Ford Motor Company and the Goodyear and Firestone Rubber companies attempted to introduce the cultivation of Hevea to those areas of South America where the tree is native. Between 1927 and 1942, Ford alone planted almost 10,000 ha in Brazil. A severe fungus disease known as South American Leaf Blight (SALB) compromised the entire effort and forced abandonment of the plantations. The causal fungus, Microcyclus ulei (endemic to Brazil), spread ultimately to all of the countries on the Caribbean rim and to Mexico. Fortunately, neither signs nor symptoms of the disease have been reported from the principal rubber producing regions in Asia and Africa.

In 1940, when war in Europe and Asia appeared imminent, the United States government attempted to develop a plantation production in Central America, Mexico, and the Caribbean islands where the disease then was absent. The U.S. Department of Agriculture (USDA) headed a consortium that included the United Fruit Company, the Goodyear and Firestone Rubber companies, various regional governments, and several private planters. The objectives and strategies of this program were outlined early in its history by Rands (1942). The prevailing view among rubber specialists of the time was that occasional escapes from the disease in otherwise badly damaged Brazilian plantings constituted evidence for inherited (genetic) resistance. Therefore, the new program proposed to elevate such resistance by continued selection and to increase latex yields by hybridization with established clones. The lifetime given to the project was 14 years, quite insufficient to accommodate the realities of multiple gene inheritance if, in fact, the genetic hypothesis had been correct. Imle (1979) described the project briefly, but Webster and Baulkwill (1989) do not mention it.

However, there was a most fortunate event early in the program. In about 1940, the USDA distributed some high-yielding, highly blight-susceptible clones from Malaya and Indonesia to cooperating Guatemalan coffee planters. Two years later, SALB invaded Guatemala, with the result that damage to these and later plantings could be observed directly and in situ. One of these clones was PB-86 (Prang Besar) from Malaysia, which still is favored today. On 29 Apr. 1947, J.F. O'Donnal, chief of the Guatemalan program, wrote a memorandum to planter Owen Smith that R.D. Rands of the USDA had observed satisfactory growth of the SALB-susceptible clones on Smith's plantation, clones that earlier had shown little promise. Smith's plantation was located on the Pacific Piedmont of Guatemala at the base of the Volcano Atitlán. [The term Piedmont, as used in physiography, denotes foothills or plateaus subtending a range of mountains as, e.g., the Appalachian Piedmont of Virginia and the Carolinas. Simmons et al. (1959) used the term Declive del Pacífico.] In retrospect, this was a most significant observation. The 6-month-long dry season was just ending in April. Smith's otherwise highly susceptible trees had undergone normal leaf fall or "wintering" followed by bud opening and refoliation during the dry months. The fundamental import of this observation seems not to have been grasped at the time. Indeed, it is not clear just when the Guatemalan planters realized that considerations of genetic resistance to SALB need not concern them. The time was not right in 1947 for the coffee planters to turn seriously 
to rubber as an alternative crop. The Pacific Piedmont was and is Guatemala's prime coffee-producing area. It was inevitable that rubber would receive scant attention while coffee prices were good. Eventually, trends in the coffee market redirected attention to rubber. But, before taking brief historical note of that movement, it is appropriate to pursue the Piedmont anomaly from the standpoint of horticultural science.

When R.D. Rands published his plan (1942) for the Central American cooperative research program on Hevea cultivation, he referred in passing to reports that environment may influence the severity of the SALB disease. Only recently has the concept received wider attention. Johnston and also Simmonds discuss it in Webster and Baulkwill (1989). They mention a suggestion made by Gasparotto and others in 1984 that $H$. brasiliensis possibly may flourish in those parts of Brazil where the dry season is long enough to restrict the spread of the disease. However, these latter references postdate the Guatemalan experience and may well derive from it. The facts are that optimal production of latex on the Pacific Piedmont has continued without interruption for 20 years and that Guatemala presently is the only country in Latin America to have developed a successful commercial production of that commodity. To account for this departure from earlier experience, it is necessary to consider alternative hypotheses for explaining observedinteractions between host and pathogen. For example, the survival of many individual trees scattered through the Brazilian forests and of the occasional isolated tree on Brazilian plantations as well as the consistently ephemeral nature of supposed resistance obtained by selection and breeding, all may be explainable in terms of environmental rather than genetic control. To an experimentalist, the very high probability of damage from SALB on plantations in Brazil and the small probability of damage on the Guatemalan Piedmont are seen more readily as extremes (limits) of a dependency continuum in which the independent variable is environmental rather than genetic. A schematic representation is presented in Fig. 1. In this case, "resistance" becomes nothing more than environmentally modulated "escape." Whether the absence of SALB in Asia and Africa results, as is supposed, from failure to import inoculum with the original planting stocks or from an environment hostile to the pathogen cannot be ascertained without the unthinkable importation and release of viable spores. In view of the enormous amounts of money and of energy expended to control SALB by breeding and selection, it appears that a systematic research program on the environmental alternative would be economically advisable. Successful outcome of such research would bring to an end a long history of disastrous site selection for the cultivation of this otherwise adaptable crop. At the same time, it would create opportunity for the flourishing of relatively small regional production industries of the sort required by emerging countries. A brief description of the Piedmont environment may call attention to some relevant variables.

The Pacific Piedmont of Guatemala extends from the border with Mexico southward in a long sweeping arc to the borderwith El Salvador. The portion that lies between Mexico and kilometer 140 at Santa Lucia Cotzumalguapa and between 200 to $750 \mathrm{~m}$ altitude contains all of the productive plantations. On the lower edge of the
Piedmont, 3 to $4 \mathrm{~m}$ of rain falls between May and October. These rains occur usually in the afternoon and cease by sundown or earlier. Upslope, rainfall increases to a maximum of 4.4 $\mathrm{m}$ at altitude $900 \mathrm{~m}$, above which it diminishes. On the lower reaches, there is virtually no rain during the dry season (November to May). Upslope, well-distributed light rains fall during the same period. Occasionally, strong, drying winds blow up from the coastal plain, and montane downdrafts during early morning hours are the rule. Preferred soil types (Simmons et al., 1959) include Suchetepéquez silt loam derived from recent, dark volcanic ash (4801 ha now in rubber); Quetzaltenango fine sandy loam derived from white pumice (3454 ha now in rubber); and Retalhuleu silty clay loam thought to derive from a pre-Quaternary land surface (1484 ha now in rubber). Stratification of volcanic mantles with materials of differing porosity and bulk density leads often to downslope rather than vertical movement of soil water. This factor may help to explain the unique suitability of the Piedmont environment for Hevea culture.

Other cultural advantages of the Piedmont include a daytime warming effect from the southern to southwest-

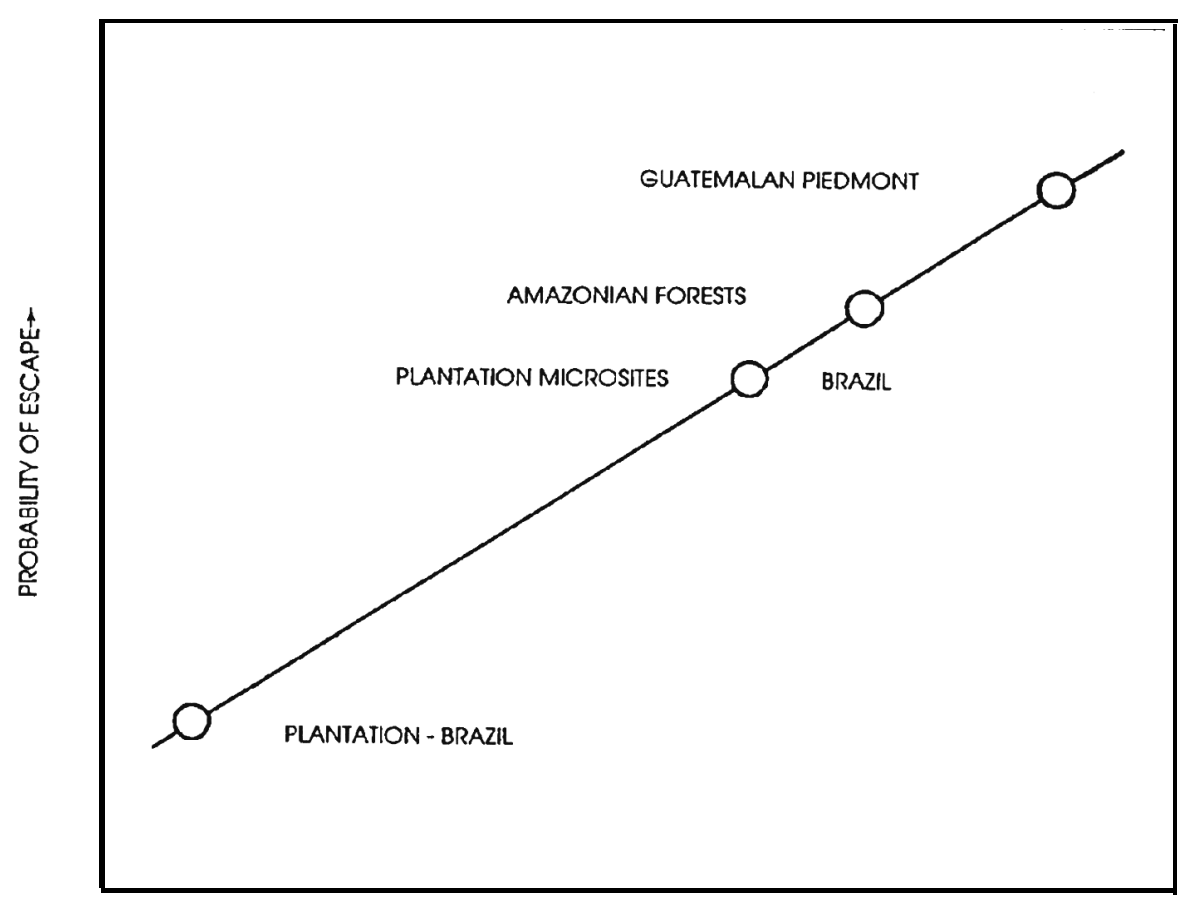

$\leftarrow$ FAVORS PATHOGEN - ENVIRONMENT - FAVOR HOST $\rightarrow$

Fig. 1. Schematic representation of the relative probabilities of escape of Hevea from South American Leaf Blight in relation to environment. Environment is defined as some composite of factors, their intensities and durations, yet to be identified and evaluated. 
ern exposure and a soil water regime characterized by abundant supply and rapid drainage. Escape from damage by SALB may be favored by drier and cooler nights associated with prevailing patterns of rainfall, by the evaporative effects of altitude, by site-related movements of air, and by a long dry season so timed as to accommodate refoliation of the trees when M. ulei is least active. The basis for these interpretations has been gleaned from a scattering of reports in Webster and Baulkwill (1989). Some conception of the effectiveness of the Piedmont environment is given by results of a survey of 201 rubber plantations in late 1990 (Gremial). Forty-eight of the enumerated locations reported damage to plantings totaling $8.6 \%$ of their trees. In all cases, damage was confined to plantings along deep ravines and watercourses where higher relative humidities would be expected.

Had not the coffee planters of Guatemala shown a pioneering, adventuresome spiritwith respect to crop diversification, the rubber, quinine, essential oils, and other valuable industries might never have taken root. But the road to success is not smooth. There is a generally accepted rule that development of a new crop requires $\approx 10$ years to acquire the horticultural technology and another 10 to build up processing technologies and marketing facilities. Planting of Hevea became a serious undertaking in about 1959, just 20 years after the first introduction of high-yielding Asian clones. The Development Loan Fund was persuaded to lend \$5 million for the purpose. Propagating stocks of clones PB86 (see above), RRIM-600 (Rubber Research Institute of Malaysia), and GT-1 (Godang Tapen) were purchased in southeast Asia. These are all highyielding clones and are highly susceptible to SALB. By 1989, 9.46 million trees had been planted on 26,400 ha of land. About $40 \%$ of these trees were in production by 1989 , when total output was $15,400 \mathrm{t}$ of crude rubber, dry basis. This amounts to about 1330 $\mathrm{kgžha}^{-1}$ and is close to the better estate yields in southeast Asia. Owing to the large areas now planted to young trees of high-yielding clones, total production from stands of all ages is expected to reach 35,100 tžyear $^{-1}$, dry basis, by 1996. So far as is known, these figures are not matched by any other rubber producing area in the Western Hemisphere.

When planting of young trees reached significant levels, a group of 15 potential producers of latex established an Asociacion de Productores de Hule in anticipation of common needs for information regarding the growing of the trees, latex processing, and marketing. In 1970, a Gremial de Huleros (Society of Rubber Growers) was authorized by the government. The Gremial established a solid legal base as a private, independent, cooperative entity. At present, there are 333 members. The group publishes a periodical, Gremhule, that provides updated technical information, reports prices, and distributes records of production. A program of regular, on-site visits by experts gives technical assistance to the growers. With the advent of crude plantation rubber production, several processing firms have arisen, among which are Introsa (Industrias Tropicales, S.A.), Inlasta (Industrias de Latex, S.A.), Heveatex, Goodyear, Cocapsa, Mariscos Hulenort, and Entre Rios. Products are various grades of crumb rubber and of latex concentrates. As of Aug. 1990, total processing capacities were 63 tžday $^{-1}$ of crumb rubber and 83 tžday $^{-1}$ of latex concentrations, dry basis. In 1990, actual usage was $70 \%$ to $80 \%$ of capacity.

Owing to the much larger scale of natural rubber production and distribution centered in southeast Asia, prices of Guatemalan rubber and rubber products are tied to those of the Singapore market. Current production in Guatemala is sold entirely to local processors, to Mexico, and to other nations of the Caribbean Basin. A crop that requires 6 to 7 years to bring into first production and that exhibits a slow rise thereafter before full production occurs does not allow for sensitive adjustment to market fluctuations. Despite the apparent world trend toward megamarkets, it seems likely that smaller regional producers such as Guatemala will retain a permanent niche. Two recent assessments of future demand for natural rubber (Economist Intelligence Unit, 1991;
Greek, 1991) foresee no substantial expansion. All of this counsels for keeping Guatemalan production within its original conceptual bounds: that is, not as a replacement but rather as a supplement to the production of coffee. The longer-term view may differ. Continued increase in populations and dwindling petroleum reserves seem likely to generate demand for alternative, renewable hydrocarbons. With appropriate chemical research, Hevea latex undoubtedly will find significant uses in addition to the manufacture of vehicular tires. Should that situation arise, successful analysis of Guatemala's Piedmont anomaly would afford a model for the growth of regional production centers elsewhere in Latin America.

\section{Literature Cited}

Greek, B.F. 1991. Rubber demand is expected to grow after 1991. Chem. Eng. News 69(19):37-54.

Imle, E. 1979. Hevea rubber-past and future. Econ. Bot. 32(3):264-277.

Rands, R.D. 1942. Hevea rubber culture in Latin America I, II, III. India Rubber World 106(3):3-19.

Economist Intelligence Unit. 1991. Rubber Trends: Why rubber prices will stay low (September issue), London.

Simmons, C.S., J.M. Tarano T., and J.H. Pinto Z. 1959. Clasificación de Reconocimiento de los Suelos de la República de Guatemala. Ministerio de Educación Pública, Guatemala.

Webster, C.C. and W.J. Baulkwill (eds.). 1989. Rubber. Longman, England.

Wright, C.H. and D. Dewar. 1900. Johnson's Gardener's Dictionary. G. Bell, London.

\section{Acknowledgements}

James R Troyer, professor of plant physiology and biomathematics, North Carolina State Univ.; John W. Hylin, retired chairman of the Dept. of Agricultural Biochemistry, Univ. of Hawaii; and Frederic Rosengarten, Jr., tropical agriculturist and well-known author (e.g., The Book of Spices), contributed importantly to this manuscript. 